\title{
Effects of Market Fundamental Variables on Property Prices in Kenya - A Case of Nairobi Residential Property Market
}

\author{
Maurice Ochieng Miregi; Prof. Alamdi Obere; \\ Senior Valuer (Knight Frank), Jomo Kenyatta University of Agriculture and Technology, Juja, Kiambu country, \\ Kenya \\ Dean of School of Business and Economics, Massai Mara University, Narok county, Kenya
}

\begin{abstract}
Property prices in Kenya are high leading to concerns over fundamentally unstable market, a situation with severe financial crisis consequences. The study seek to dispel this fear, using VAR model. Property pricesis the dependent variable while stock prices, interest rate, building cost and inflationare the independent variables. The results showproperty price that is reliant on its lagged values. Inflation and interest rate have insignificant lagged positive and negative effectsproperty prices while neither stock prices nor building cost can explain the prevailing property prices. The findings are consistent with the theories that property investment is a hedge against inflation, property prices are inversely related to interest ratesand inefficiency of the property market as evident in the time lapse required for adjustments. The study implies a fundamentally weak property market, an empirical facts that emulates a price bubble requiring necessary policy steps to supress.
\end{abstract}

Keywords: Property price, market fundamental variables, interest rate, inflation, stock price, building cost

\section{Introduction}

The result of incredible asset price increases is severe financial crises as witnessed in the Asian, DotCom, global economic crunch and European debt crisis. Most importantly, the global financial crisis confirmed how challenging it is for authorities across the world to maintain asset market stability particularly in the property sector, which has strong linkages with the larger economy. Property is used by all as workplaces or by households as places of residence. Its value can easily make up the largest single component of wealth of citizens of a country (DiPasquale \& Wheaton, 1992) while its purchase is predominantly funded by mortgage loans originated by financial institutions. The use of real property as collateral for bank loans creates strong linkages between property and credit markets, and by extension the banking sector and the macro economy Hitherto, real property prices in Kenya have been on an upward trend leading to concerns over fundamentally unstable market. While other property markets across the world dipped, the Kenyan environment remained strong, confounding many in the region since 2002 (Kariuki, 2012). A study by Knight Frank found out that the asset prices jumped by $25 \%$ in 2011 . The firm ranked Nairobi $11^{\text {th }}$ out of 28 cities and the top African city in terms of property price followed by Cape Town in its 2013 Q2 Prime Global Cities Index. The report further shows that between 2011 and 2012 the property sale price rose in double digit figures while the period between June 2012 and March 2013, the prices in the up-market of Nairobi, alone increased by 8.4 per cent.

The trend is puzzling, especially when interest rates increased at the end of 2011, amid weakening shilling heading into the 2013 general elections (Kariuki, 2012). Warnings of dire straits like in the US during the $2008-2010$ could not scare off investors. In 2011, there were again predictions that the bubble bust was real, owing to interest rates that had increased from a low of $14 \%$ to more than $24 \%$. Instead, the market has been bullish with prices of a three bedroom apartment in up market areas of Nairobi like Kilimani, Kileleshwa and Lavington reportedly selling at unparalleled Kshs $15-25$ million, especially when an average monthly rent obtainable from the same is Kshs 70,000/- only. The prices are not in sync with the achievable rent on most of the properties (Mwangi, 2011). The yield remains much lower than interest rate despite high leveraging in the property markets with rent being the basic return on capital. Any adverse development in the property market can easily have a material impact, especially on the households' wealth and banking system's health (Malpezzi $\&$ Wachter, 2002).

The manifestation of property price bubble will not only threaten the stability of the property market but would most importantly mean that the market is not necessarily allocating the savings of individuals to the best possible investment uses (Flood \& Hodrick, 1990).The objective of the study is to investigate the effect of market fundamental variables on the property prices in Kenya, particularly the residential property market of Nairobi. If fundamental factors can provide a good explanation for the prevailing prices then the continued perception of property price bubble is misplaced. The market fundamental variables of interest include the inflation, stock prices, interest rate, and building cost. The study therefore seeks answers to the following questions: 
i. What is the relationship of inflation and the residential property prices for Nairobi?

ii. How does interest rate affect the residential property prices in Nairobi?

iii. How does stocks price relate to the residential property prices in Nairobi?

iv. What is the influence of building cost in the residential property prices of Nairobi?

The study uses Nairobi Stock Exchange 20 share market index to proxy the trends of stock prices. It argues for the existence of a substitution effect between financial assets and real estate prices. The higher returns in one market will shift investment away from the other market and cause its price to decline. The study therefore hypothesizes that the two variables should move in the opposite directions.

Lending interest rate is used to proxy interest rates which the study believes should not only capture the cost of borrowing for purchasing property and real estate yields but also the state of investment opportunities as far as alternative assets investment is concerned. Together with other aspects such as, growth in rentals, risk and taxation, long interest rate is reflected in the capitalization rate.

Quantity of new housing units affect the supply side of real estate units and the study considers it to show how property prices will influence production of new units. The higher the prices the more quantity would be expected in the market. The study uses the building cost index which is also composed of cement consumption.

Consumer price index is used to proxy for inflation. The study considers real estate investment as a hedge against inflation; a claim propagated by the Gordon growth Model. The theory argues that real property is a long - lived with income that adjusts to inflation unlike, most fixed income products. Trend of property price is therefore expected to be directly proportional to inflation.

\section{Literature Review}

Studies relating to this topic are limited in Kenya but immense in the developed economies, especially in the immediate period following financial crisis. The scarcity of these studies in Kenya simply mean that all interested parties in Kenya's property market cannot predict property prices trend. Quigley (1999) poses the question as to whether fundamentals explain property price. The outpouring of research on the topic underscores the lack of consensus about the correct approach for forecasting real estate price changes. Indeed studies vary in both their geographic scope and attention to the complexity of the property markets studies due to multifaceted market fundamental factors (Zainuddin, 2010) and the general lack of standardized methods to measure (Flood \&Hodrick, 1990).

The market fundamentals determining property prices can be divided into supply and demand factors, which affect the asset price differently. Whereas positive demand shocks will tend to increase real estate asset prices, positive supply shocks increase costs thereby acting in the opposite direction (Case, et al., 2011).On this account, definitely, there are myriad of fundamental factors affecting property prices. This study however investigates only four market fundamental variables which are; interest rate, buildings cost, stock prices and inflation. The choice of these explanatory variables is informed by the fact that towards the end of the year 2011, Kenyan economy experienced very unpredictable movements in most of these variables. For instance, very high lending interest rate and inflation (Elly \& Oriwo, 2012) were witnessed in the recent past. World Bank (2011) confirms that lack of affordability of housing as a combination of factors which includes the low levels of income and the high and volatile level of inflation and relatively high margins charged by banks. Issues on the supply side - represented in this case by building cost - also creates a price barrier for many, where the cost of even the most basic new house is out of reach for the vast majority (World Bank, 2011). Surprisingly all these did not deter property developers or buyers (Kariuki, 2012). It is against this continued growth of property prices contrary to the expected influence of these selected market fundamental variables that the researcher seeks to empirically explore their respective and combined effect on the property prices in the country and specifically Nairobi.

\subsection{Interest rate}

Abraham \&Hendershott (1996) develop a model of housing price change that allows for a lagged adjustment process. They find among other factors they investigated that appreciation in property prices are negatively related to rises in real interest rates. According to Liow (2004) interest rates has been used in a number of studies to proxy for expectations about future economic conditions and capture the state of investment opportunities. Lending interest rates in particular, affects an individual's ability to purchase residential property as well as cost of financing. It also represents return on substitute investments since it represents the yield on competing asset(Kariuki, 2012). When borrowing cost is low, it helps the property holders to raise more finance from the banks against their assets, leading to increases in property prices (Mahalik \& Mallick, 2010).

The standard Gordon Growth Model which can be interpreted in the case of property to mean that Property Price $=$ Rent/ (Interest Rate - Rental growth rate), implies a convex relationship between property 
prices and interest rates such that the lower the level of the interest rate, the greater is the elasticity of property prices to changes in interest rates. Cheap loans resulting from low levels of interest rates should therefore tend to increase demand for property thereby pushing up prices. Low interest rates also reduces the user cost because the cost of debt financing is lower, as is the opportunity cost of investing equity in a property (Himmelberg, et al., 2005).

Moreover, aspects such as long term interest rates, growth in rentals, risk and taxation influence real estate yields and are reflected in the capitalization rate (DiPasquale \& Wheaton, 1992).If interest rates in the economy rise, the capitalization rate rises and investors demand a higher return from real estate. Higher returns cannot be realized from current rents and the yield from real estate becomes low relative to other investment options. Investors will therefore shift their funds from real estate to other investments in their portfolios. Under these conditions, the capitalization rate rises lowering real estate asset prices. The converse may also occur, causing asset prices to rise

\subsection{Stock prices}

Investigating whether stock markets and real estate markets are integrated or segmented in both the US and the UK, Apergis\&Lambrinidis (2011) reveal that the two markets are integrated, with the relationship increasing when the securitized real estate markets are considered. Notably the two markets are parts of a larger economywhich are crucial to investors aiming at well diversified portfolios, in such a way that the non systematicrisk is totally eliminated.Price inflation in one asset will however influence the investment decisions resulting into reallocation of resources to portfolios, affecting price of the other asset. This substitution effect suggests that prices of the two should move in opposite directions, as higher returns in one market will shift investment away from the other market and cause its price to decline. But the wealth effect predicts that an increase in equity (or property) prices arising from the increased value of aholding, will allow households to expand their investment in both markets. As a result, the two asset prices will tend to move in the same direction (Zhu, 2003).

Moreover, many listed firms, property is both a factor of production and an asset (Liow, 2004). According to Apergis\&Lambrinidis (2011) changes in the prices of real estate lead to changes in corporate profitability which trickles to the stock prices of those corporations since real estate assets affect the asset side of corporate balances sheet that reflect higher or lower prices for their fixed assets. The changes also reflect analogous changes to the credit capacity of the corporation since as they affect the capacity of the corporation to use fixed assets as collateral in obtaining more bank loans. This changing borrowing capacity is automatically reflected as changes in the capacity to implement more investment projects and as a result, the corporations' book value changes, leading to dynamic stock market prices. The situation implies a positive association between real estate returns and the stock market such that in good times, corporate growth in profitability (with higher share prices) leads to corporate expansion which further leads to rising rental level given increased demand and short - run supply inelasticity. Rising rents lead to higher capital values in the property markets and hence raise net asset values anticipated in the stock prices (Liow, 2004). In a recession, the reverse process happens.

\subsection{Inflation}

Case, et al. (2011) suggest that a variety of assets have inflation - protecting characteristics. Abelson, et al. (2005) confirms this position while investigating a number of determinants of housing price for Australian during the period 1970-2005. Among factors they investigated, they find that property prices are positively related to inflation rate in the long-run. Real property is considered a strong inflation hedge on conceptual grounds and performs as well as, or better than, other inflation-sensitive assets and do not expose investors to significant directional inflation risk. The claim is embedded in the Gordon growth Model that argues that the asset is long - lived with income that adjusts to inflation unlike, most fixed income products. The model argues that real estate asset prices are given by the net present value of the future rent cash-flow stream, assumed to grow indefinitely at a constant rate, discounted at an appropriate nominal rate. Assuming no change in the real economy, inflation will affect the discount rate and the rent growth rate in equal measure, and will therefore have no impact on capitalization rates in inflation-adjusted terms.

\subsection{Building costs}

Building costs affects the supply schedule for new construction such that high construction costs may serve as indicators of factors that reduces the short-run responsiveness of supply to demand shocks (Hlaváček \& Komárek, 2009).Abraham and Hendershott (1996) find construction cost as significant in predicting property prices across US metropolitan property markets. Hlaváček\&Komárek (2009) confirms this position in the Czech Republic, though in its weak form and even reveals that in some periods the relationship is negative because property price shows little variability over time. Jud and Winkler (2002) show only lagged construction cost 
variable as statistically significant, while the current construction cost variable is not. The result is not surprising based on the time delay in construction and the expectation that cost impacts to the existing home markets would rise only after new property prices adjust to higher construction costs.

\section{Methodological Framework}

The study takes an explanatory design, which seeks to establish the importance of the variables of interest in the determination of property prices and how quickly and strong the prices react to the respective changes in Kenya. The data included in the study are monthly time series for the period between January 2001 and December 2013. The choice of period is purely based on the availability of data series while the monthly aspect not only helps in understanding short run effects of the variables but offers the study substantial frequency to investigate for the much needed reliability. Notably, the period represents just when property prices began to rise in the country. According to Knight Frank property prices began to increase the period following election of the NARC government. The period brought much optimism and the economy started to improve significantly.

Monthly data on property prices proxied by HPPI are obtained from Hass Consult Limited data base. The index is the only publicly available index in the country. Its data is available on a monthly basis with Dec. 2000 being the base period. NSEI is used as a proxy for the stock prices - the data is available on daily, monthly, and/ or yearly basis. The data on the lending interest rate used as a proxy for the interest rate is obtained from CBK and is also available on a monthly basis from July 1991. Finally data on both CPI and residential buildings cost index, proxing inflation and building cost respectively, are obtained from KNBS and is available mainly on a monthly basis from 1962. All the data are tested for stationarity using KPSS to verify lack of spurious results due to the effect of a common trendThe choice of KPSS over other available tests is that it complements unit root tests such as the Dickey-Fuller tests by testing both the unit root hypothesis and the stationarity hypothesis (Kwiatkowski, et al., 1992), and can therefore distinguish series that appear to be stationary, have a unit root, and whose data are not sufficiently informative - a surety for stationarity or integration.

The study adopts the unrestricted vector autoregressive (VAR) model as proposed by Sims (1980) where all the variables are assumed to be endogenous with each in the system regressed on a given number of lags of itself and the same number of lags for all other variables in the system. The model is crucial in studying the joint behaviour of variables by providing empirical evidence on the response of macroeconomic variables to various exogenous impulses in order to discriminate between alternative theoretical models of the economy.

As discussed above the variables that are included in the model are property prices (PP), percentage change on stock prices (SP), interest rate (IR), and building cost (BC). Thus the model takes the form of:

$\mathrm{PP}_{\mathrm{t}}=\propto_{0}+\mathrm{PP}_{\mathrm{t}-\mathrm{i}}+\propto_{1} \mathrm{SP}_{\mathrm{t}-\mathrm{i}}+\propto_{2} \mathrm{IN}_{\mathrm{t}-\mathrm{i}}+\propto_{3} \mathrm{IR}_{\mathrm{t}-\mathrm{i}}+\propto_{4} \mathrm{BC}_{\mathrm{t}-\mathrm{i}}+\varepsilon$

Where $\mathrm{PP}_{\mathrm{t}}$ is the property prices at time $t$ while $\mathrm{PP}_{\mathrm{t}-\mathrm{i}}, \mathrm{SP}_{\mathrm{t}-\mathrm{i}}, \mathrm{IN}_{\mathrm{t}-\mathrm{i}}, \mathrm{IR}_{\mathrm{t}-\mathrm{i}}$, and $\mathrm{BC}_{\mathrm{t}-\mathrm{i}}$ represents the respective lagged property prices, stock prices, inflation, interest rate, and building costs; with irepresenting the number of lags, assumed to be free to take on any value. The $\propto_{0}, \propto_{1}, \propto_{2}, \propto_{3}, \propto_{4}$ in the equation represents the coefficients of the independent variables to be estimated by the VAR model while the $\varepsilon_{\mathrm{t}}$ is a random error term at a given time. The error arises from the fact that the study cannot capture every influence on an economic variable in the model (Greene, 2002). The possibility of lags in the property market adjustment process is examined by including into the equation the lagged values of independent variables; but most importantly to suit the condition in the unrestricted VAR model, requiring each variable in the system to be regressed on a given number of lags of itself and the same number of lags of all other variables in the system. In our case the lags make sense in that they represent the adjustment process in the property market.

\section{Data, Estimation and Empirical Results}

The data used are from $2001 \mathrm{~m} 01$ to $2013 \mathrm{~m} 12$. The real data are presented in the table 1 and graphical representation figure 1 forming part of the appendices to this study. The data show systematic dynamics in the trends of property prices, inflation and stock prices. It also shows a drastic drop in the interest rates in 2003 prior to some sort of stability before rising again in 2011/2012. Building cost on the other hand has persistently risen in the past.

Stationarity tests on the data for each variable at level with intercept and with trend and intercept are conducted using KPSS as summarized in the results in table 2. Sims (1980) discourages differencing because as Mahalik\&Mallick (2007) note "it throws away" information concerning the co-movement in the data, which in general, leads to poor forecasting. The study therefore seek stationarity at level with new variables in form of percentage change for those that required differencing. All the variables can be estimated in a variety of specifications and forms including logarithmic models and/ or percentage change models without losing their significance. To this regard the study adopts percentage change in property prices proxied by HPPI, stock prices proxied by NSE 20 Share Index and the percentage change in the CPI. The percentage changes of property prices, stock prices and CPI do not lose meaning of the data but also represent the respective return for the two 
markets and the inflation rate. For instance in the in the percentage change form, the dependent variable property prices - just like stock prices and inflation could be represented by the one-period percentage changes $(\Delta \mathrm{P} / \mathrm{P})$ derived by $\left\{\frac{\mathrm{PP}_{\mathrm{t}}-\mathrm{PP}_{\mathrm{t}-1}}{\mathrm{PP}_{\mathrm{t}-1}}\right\} * 100$, which represent the return for the respective market and the inflation rate.in the percentage change specification; the variables are expressed as percentage changes.

KPSS is a right sided test with critical values tests at $1 \%, 5 \%$ and $10 \%$ being $0.739,0.463$ and 0.347 respectively for at level with intercept and $0.216,0.146$ and 0.119 respectively for data with trend and intercept. Table 3 summarizes the results of stationarity tests of the data used in the VAR model with the results showing all the data stationary at level. The data used in the test include the percentage change in the property prices (PP) proxied by Hass Consult Property Index, percentage change in the stock prices (SP) proxied by Nairobi Stock Exchange 20 Share Price Index, percentage change in the inflation (IN) proxied by Consumer Price Index, Building cost (BC) proxied by Residential Building Cost Index, and Interest rate (IR) proxied by banks weighted lending interest rate. The results show that all data are stationary at level and are therefore integrated of order I (0) at least at significance level of $95 \%$.

The application of unrestricted VAR involves selection of appropriate lag intervals for the endogenous variables. According to Mahalik\&Mallick (2010) inappropriate lag selection may give rise to problems of over parametrization or under parametrization. The selection for optimal number of lags in the VAR model has five conditions, i.e. the Likelihood Ratio (LR), Final Prediction Error (FPE), Akaike information criterion (AIC), Schwarz information criterion (SIC), and Hannan-Quinn criterion (HQ) to select the optimal lag lengths.Table 3 lists the results, where LR selection criteria selects for lag three while the rest including FPE, AIC, SC, and HQ select for the lag one.

\subsection{Property Prices}

Tested at $5 \%$ and $10 \%$ levels of significance with respective critical $t$ values of 1.645 and 1.282 , the VAR estimate results in table 4 indicate only lagged percentage change of property prices viz percentage change of the HPPI as being significant in the determination of the current prices; meaning current property prices can predict 26.00 percent of property prices of one month ahead. The result however rejects the hypothesis that market fundamental variables affect property prices in the country, at least for those market fundamental variables under our investigation. This is not ideal for a well-functioning property which according to Case, et al. (2011) market fundamental factors determining property prices can traditionally be divided into supply and demand factors with either factors affecting the asset price differently.

Further tests with 3 lags, whose VAR estimate results are presented in the table 5, not only confirms the importance of the lagged property prices in the determination of property prices but also reveal that inflation and interest rates are also important variables at $10 \%$ level of significance. The result just like with the selected optimal lag 1 confirms the importance of the lagged value of property prices in determining the future prices. Property prices today can estimate those of 3 months ahead. The effect of the property price one month ago and for the previous quarter however indicates considerable positive effects of $21.914 \%$ and $16.500 \%$ respectively. The interpretation of this result is actually traceable from the theory of bubble creation whose implication should worry the policy makers, because when the upward trend is only supported by property prices itself and not market fundamentals, the situation can be regarded as bubble, requiring swift and appropriate interventions.

\subsection{Inflation}

The VAR estimate results reveal importance of the inflation viz by percentage change in the CPI for 3 months ago in determining property prices in the country, though with a very negligible positive effect of $0.672 \%$. The positive effect which is consistent with the findings of Abelson, et al. (2005), is actually traceable from the fact that in situation of high inflations demand for real property would increase as investors tend to secure their respective investments from the inflationary pressures. This is consistent with the theory of property investment being used as a hedge against inflation (Investment Property Forum, 2011); a claim propagated by the Gordon growth Model that argues that real estate is a long-lived with income that adjusts to inflation unlike, most fixed income products.

\subsection{Interest Rates}

Some coefficients of interest rate viz banks weighted lending interest rate are important in the determination of property prices, though with a lagged effect of two months which is consistent with the findings of Abraham \&Hendershott (1996). The results indicate a negative effect, meaning current interest rates can predict at least $0.4 \%$ of property prices two months ahead. The lagged negative effect is further consistent with the inverse relationship theory of property prices and interest rates, which ordinarily would not be immediate because of time lapse for adjustments. Interest rate has implication on the equilibrium return on property investment as it affects the cost of financing and returns on substitute investments since it represents the yield on competing asset(Kariuki, 2012). High interest rates would discourage investors into buying real 
property thereby reducing demand and consequently prices. This was actually witnessed in 2011, a period when interest rates were high amid weak shilling. This deterred property developer and/ or property buyer's participation in the market and prices actually stagnated.

Interest further impacts on house prices via its effects on supply of new homes: for instance, low mortgage rates may stimulate new homes sales, thus reducing supply and so raising house prices generally (Conefrey \& Whelan, 2011). The mortgage interest rate thus acts in the opposite direction, as growth in the mortgage rate makes loan financing of property purchases less attractive and increases households' repayments of existing loans. Cheap loans resulting from low levels of interest rates should therefore tend to increase demand for property thereby pushing up prices. Most importantly the result confirms the proposition of the capitalization model in the determination of property prices that implies a convex relationship between house prices and interest rates such that the lower the level of the interest rate, the greater is the elasticity of property prices to changes in interest rates.

\subsection{Stock prices}

As far as Stock prices viz the percentage change in stock prices i.e. return for the stock market, the study reveals no coefficient as being important in the determination of property prices. We can attribute this to lack of representation of property investors in the Nairobi Stock exchange whose index was used. Apergis\&Lambrinidis (2011) note that the real estate and stock markets are somewhat integrated only with the relationship increasing when the securitized real estate markets are considered. Liow (2004) only managed to trace the relationship between stock and real estate markets by considering residential and office property markets in a three-index cointegrated system (all-stock price index / property stock price index, residential price index and office price index). In this case, real estate is a component of the stock market, which enabled the assessment of the combined and relative impacts of residential and office property prices on all-stock and property stock prices respectively. As for the case of Nairobi, currently no real estate market data can be traced in the Nairobi Stock Exchange Index, the proxy for stock prices in the study. The Nairobi Stock Exchange is currently exploring and have laid out guidelines for the introduction of REITs whose inclusion in the index is expected to reveal the contribution of real estate in the stock market.

\subsection{Building Cost}

Like stock prices, the study reveals no coefficient of building cost viz residential building cost index as being important in the determination of property prices against the usual proposition whereby construction of new property is expected to determine the price (Hlaváček \& Komárek, 2009). The explanation to the prevailing situation in the property market for Nairobi could be abnormal profits that are still realizable in real estate investments. The gap between production cost and revenues are still incomparable, as developers continue to report huge returns on investment. Building cost is also one of the supply factors of the real estate market that according to Hlaváček \& Komárek (2009) often pass through to property prices with a long lag (which the study did not explore) due to the long time it takes to prepare and actually implement a construction project.Hlaváček \& Komárek (2009)find weak correlation of apartment prices with construction prices and further reveal that some periods the relationship is even negative because property price shows little variability over time. Though Jud and Winkler (2002) find that property price appreciation positively responds to construction costs, they confirm that only lagged construction cost as being statistically significant and not the current construction cost. Their expectation for the positive relationship is that cost impacts to the existing property markets would rise only after new property prices adjust to higher construction costs.

\subsection{Impulse Response Function}

Impulse response analyses are carried out to indicate the VAR system's dynamic behaviour, in this case; by predicting the responses of property price to various shocks in its fundamental variables. It therefore shows how a variable responds to one standard deviation shock in another variable of interest and trace out the response of current and future values of each of the variables to a one-unit increase (or to a one-standard deviation increase, when the scale matters) in the current value of one of the VAR errors, assuming that this error returns to zero in subsequent periods and that all other errors are equal to zero.

\section{Summary And Conclusion}

Although, Kenya's situation may be unique to that of the advanced economies, these tale tells of property market crisis cannot be ignored. On the other hand it is far from surprising to find a non-fundamentally supported property market reaction leading to high price of housing relative to other goods and services; because purchasing a property is by far the largest single economic transaction made in their lifetime. Property market is also unlike markets for many other goods and services because of the dual function of the asset as a commodity, yielding a flow of consumer services and also as an investment asset which accounts for a large 
portion of household net worth. On the basis of the overall objective whether market fundamental variables have effect on the property prices in Kenya, the study reveals a pricing trend that is not fundamentally supported, at least by the variables investigated. It reveals little if not only insignificant effect of interest rates and inflation while stock prices and building cost have no effect on the property prices except for a huge influence of property prices itself; a fact that is central to creation bubbles, whose correction have detrimental effects on the larger economy, as witnessed in the USA subprime mortgages.

The study reveals significant influence of lagged property prices in the determination of those in the following period, a fact which could indicate the prevailing property pricing trend as a bubble thus requiring further investigations into whether the situation is a bubble or not. Whilst the study was limited to the four market fundamental factors determining property prices; the stock prices, building cost, inflation and interest rate; the study that there are a myriad of marketfundamental factors affecting the property sector. These fundamental factors may have substantial effect and there need to further the study into these area, most importantly to establish what actually drives the property prices before declaring the situation as a bubble.

The study also fails to show any relationship between property and stock prices, despite huge theoretical and empirical evidences linking stock as an alternative investment to real estate. To this effect we recommend further investigation into the relationship between real estate and stock markets in Kenya. Likewise, building cost is a critical determinant of property prices on the supply side of the property market which the study fail to relate with property prices; hence the need to explore further the significance of supply factors including building cost in the determination of property prices.

\section{References}

[1]. Abelson, P., Joyeux, R., Milunovich, G. \& Chung, D., 2005. Explaining House Prices in Australia: 1970-2003. The Economic Record, 81(255), pp. 96-103.

[2]. Abraham, J. M. \& Hendershott, P. H., 1996. Bubbles in the Metropolitan Housing markets, USA: Fennie Mae Foundation, Journal of Housing Research, Vol 7, Issue 2.

[3]. Apergis, N. \& Lambrinidis, L., 2011. More Evidence on the Relationship between the Stock and the Real Estate Market. Journal of Economic Literature, Issue 85 .

[4]. Case, B., Wachter, S. M. \& Worley, R. B., 2011. Inflation and Real Estate Investments, s.1.: s.n.

[5]. Case, K. E. \& Shiller, R. J., 2004. Is there a bubble in the housing market?, Yale University, New Haven, Connecticut: Cowles Foundation.

[6]. Conefrey, T. \& Whelan, K., 2011. Supply, Demand and Prices in the US Housing Market, s.l.: s.n.

[7]. DiPasquale, D. \& Wheaton, W. C., 1992. The Markets for Real Estate Assets and Space: A Conceptual Framework. Journal of the American Real E.state and Urban Economics Association, 20(1), pp. 181-197.

[8]. Elly, O. D. \& Oriwo, A. E., 2012. The Relationship Between Macro Economic Variables And Stock Market Performance In Kenya. DBA Africa Management Review, 3(1), pp. 38-49.

[9]. Flood, R. P. \& Hodrick, R. J., 1990. On Testing for Speculative Bubbles. The Journal of Economic Perspectives, Vol. 4, No. 2., pp. 85-101.

[10]. Greene, W. H., 2002. Econometric Analysis. Fifth Edition ed. Upper Saddle River, New Jersey: Prentice Hall.

[11]. Himmelberg, C., Mayer, C. \& Sinai, T., 2005. Assessing High House Prices: Bubbles, Fundamentals, and Misperceptions. Journal of Economic Perspectives.

[12]. Hlaváček, M. \& Komárek, L., 2009. Housing Price Bubbles and their Determinants in the Czech Republic and its Regions, Prague: Czech National Bank - Working Paper Series 12.

[13]. Investment Property Forum, 2011. Property and inflation, s.1.: s.n.

[14]. Jud, G. D. \& Winkler, D. T., 2002. The Dynamics of Metropolitan Housing Prices. JRER, 23(1/2).

[15]. Kariuki, C., 2012. The Factors Affecting Residential Property Values in Nairobi, Kenya. Montevideo, Uruguay, s.n.

[16]. Kwiatkowski, D., Phillips, P. C., Schmidt, P. \& Shin, Y., 1992. Testing the null hypothesis of stationarity against the alternative of a unit root - How sure are we that economic time series have a unit root?. Journal of Econometrics, Volume 54, pp. 159-178.

[17]. Liow, K. H., 2004. DYNAMIC RELATIONSHIP BETWEEN STOCK AND PROPERTY MARKETS. s.l., s.n.

[18]. Mahalik, M. K. \& Mallick, a. H., 2010. What Causes Asset Price Bubble in an Emerging Economy? Some Empirical Evidence in the Housing Sector of India. JEL.

[19]. Malpezzi, S. \& Wachter, a. S. M., 2002. The Role of Speculation in Real Estate Cycles. Seol, Lincoln Institute of Land Poliy, Cambridge, Mass.

[20]. McCarthy, J. \& Peach, R. W., 2005. Is There a "Bubble" in the Housing Market Now?, New York: JEL Classification: R21, R31, E32.

[21]. Mwangi, G. G., 2011. Behavioural Factors Influencing Investment Decission in the Kenyan Property Market, Nairobi, Kenya: School of Graduat Studies, Strathmore University.

[22]. Quigley, J. M., 1999. Real Estate Prices and Economic Cycles. INTERNATIONAL REAL ESTATE REVIEW, 2(1), pp. 1 - 20.

[23]. Sims, C. A., 1980. Macroeconomics and reality. Econometrica, 48(1), pp. 1-48.

[24]. Stiglitz, J. E., 1990. Symposium on Bubbles. The Journal of Economic perspectives, Vol. 4, No. 2 , pp. 13 - 18.

[25]. The World Bank, 2013. Kenya Economic Update; Time to shift gears, accelerating growth and poverty reduction in the new Kenya, s.l.: s.n.

[26]. World Bank, 2011. Developing Kenya's Mortgage Market, Washington: The World Bank.

[27]. Zainuddin, Z., 2010. An Empirical Analysis of Malaysian Housing Market: Switching and Non-Switching Models. Lincoln University: s.n.

[28]. Zhu, H., 2003. The importance of property markets for monetary policy and financial stability. Basel, Switzerland, Bank for International Settlements. 
Effects of Market Fundamental Variables on Property Prices in Kenya - A Case of ....

\begin{tabular}{|c|c|c|c|c|c|c|c|c|c|c|c|c|c|}
\hline & Jan & Feb & Mar & Apr & May & Jun & $\begin{array}{l}\text { Jul } \\
2001\end{array}$ & Aug & Sep & Oct & Nov & Dec & $\begin{array}{l}\text { Year } \\
2001\end{array}$ \\
\hline PP & 0.003 & 0.000 & 0.012 & 0.019 & -0.015 & -0.016 & -0.012 & 0.000 & -0.005 & 0.043 & 0.039 & 0.011 & 0.007 \\
\hline SP & -0.009 & 0.019 & -0.053 & -0.034 & -0.075 & 0.013 & -0.022 & -0.071 & -0.070 & 0.051 & -0.036 & -0.046 & -0.028 \\
\hline IN & -0.02 & 0.15 & 0.07 & 0.04 & 0.24 & 0.34 & 0.08 & 0.05 & 0.24 & -0.04 & 0.33 & 0.25 & 0.14 \\
\hline IR & 20.3 & 20.1 & 20.2 & 19.6 & 19.2 & 19.3 & 19.7 & 19.5 & 19.4 & 19.8 & 19.4 & 19.5 & 19.7 \\
\hline \multirow[t]{2}{*}{$\mathrm{BC}$} & 3194.8 & 83194.8 & 3197.2 & 3197.2 & 3197.2 & 3197.2 & 3197.2 & 3197.2 & 3220.9 & 3241.6 & 3241.6 & 3241.6 & 3209.9 \\
\hline & & & & & & & 2002 & & & & & & $\underline{2002}$ \\
\hline PP & -0.002 & 20.044 & 0.030 & 0.010 & 0.011 & 0.024 & 0.052 & -0.005 & 0.005 & 0.014 & 0.003 & 0.029 & 0.018 \\
\hline SP & -0.009 & -0.022 & -0.100 & -0.046 & -0.051 & 0.015 & 0.010 & -0.050 & -0.015 & 0.087 & 0.041 & 0.173 & 0.003 \\
\hline IN & 0.71 & -1.60 & -0.69 & 0.58 & -0.99 & -0.67 & 0.26 & 0.14 & 0.02 & -0.06 & -0.36 & -0.65 & -0.28 \\
\hline IR & 19.3 & 19.2 & 18.9 & 18.7 & 18.5 & 18.4 & 18.1 & 18.1 & 18.1 & 18.3 & 18.1 & 18.3 & 18.5 \\
\hline \multirow[t]{2}{*}{$\mathrm{BC}$} & 3347.7 & 73337.6 & 3347.7 & 3314.3 & 3314.3 & 3314.3 & 3324.7 & 3324.7 & 3379.8 & 3515.1 & 3515.1 & 3572.2 & 3384.0 \\
\hline & & & & & & & 2003 & & & & & & 2003 \\
\hline PP & $\overline{-0.002}$ & -0.020 & 0.000 & 0.010 & 0.005 & 0.015 & -0.018 & 0.002 & 0.029 & 0.010 & 0.002 & 0.004 & 0.003 \\
\hline SP & 0.109 & 0.031 & 0.032 & 0.149 & 0.124 & -0.068 & 0.036 & 0.051 & 0.130 & 0.032 & 0.114 & 0.000 & 0.062 \\
\hline IN & -0.50 & -0.17 & -0.36 & -0.15 & -0.28 & 0.08 & 0.21 & 0.24 & 0.05 & -0.15 & 0.01 & 0.07 & -0.08 \\
\hline IR & 19.0 & 18.8 & 18.5 & 18.6 & 18.5 & 15.7 & 15.3 & 14.8 & 14.8 & 14.8 & 14.1 & 13.5 & 16.4 \\
\hline \multirow[t]{2}{*}{$\mathrm{BC}$} & 3686.2 & 23686.2 & 3686.2 & 3709.5 & 3709.5 & 3765.4 & 3768.8 & 3768.8 & 3768.8 & 3815.1 & 3836.9 & 3915.4 & 3759.7 \\
\hline & & & & & & & 2004 & & & & & & 2004 \\
\hline PP & 0.011 & 0.029 & -0.005 & 0.008 & 0.011 & -0.020 & 0.001 & 0.008 & -0.015 & -0.009 & -0.007 & 0.004 & 0.001 \\
\hline SP & 0.153 & 0.005 & -0.127 & -0.023 & -0.007 & -0.119 & 0.143 & 0.000 & -0.014 & 0.060 & 0.031 & 0.010 & 0.009 \\
\hline IN & -0.09 & -0.08 & 0.16 & 0.09 & 0.39 & -0.28 & -0.44 & -0.85 & -0.20 & 0.04 & 0.05 & 0.02 & -0.10 \\
\hline IR & 13.5 & 13.0 & 13.1 & 12.7 & 12.6 & 12.2 & 12.3 & 12.2 & 12.3 & 12.4 & 12.0 & 12.3 & 12.5 \\
\hline \multirow[t]{2}{*}{$\mathrm{BC}$} & 3932.1 & 13996.6 & 3999.1 & 4144.4 & 4144.4 & 4144.4 & 4153.2 & 4153.2 & 4153.2 & 4153.2 & 4153.2 & 4185.9 & 4109.4 \\
\hline & & & & & & & 2005 & & & & & & 2005 \\
\hline PP & 0.019 & 0.001 & 0.028 & 0.004 & 0.010 & 0.012 & 0.003 & -0.003 & 0.001 & -0.010 & 0.015 & 0.010 & 0.007 \\
\hline SP & 0.050 & 0.039 & -0.001 & 0.006 & 0.086 & 0.133 & 0.003 & -0.011 & -0.027 & 0.028 & 0.009 & -0.000 & 0.026 \\
\hline IN & 0.13 & 0.06 & -0.02 & -0.13 & 0.08 & 0.19 & 0.01 & 0.42 & 0.38 & 0.13 & -0.25 & -0.06 & 0.08 \\
\hline IR & 12.1 & 12.4 & 12.8 & 13.1 & 13.1 & 13.1 & 13.1 & 13.0 & 12.8 & 13.0 & 12.9 & 13.2 & 12.9 \\
\hline $\mathrm{BC}$ & 4157.6 & 64157.6 & 4157.6 & 4230.9 & 4230.9 & 4230.9 & 4230.9 & 4230.9 & 4230.9 & 4325.4 & 4325.4 & 4452.2 & 4246.8 \\
\hline
\end{tabular}

2006

\begin{tabular}{llllllllllllll} 
& \multicolumn{10}{c}{2006} & \multicolumn{10}{c}{0} \\
\hline SP & -0.001 & 0.005 & -0.005 & 0.003 & 0.018 & 0.021 & 0.018 & 0.012 & 0.028 & 0.010 & 0.008 & 0.002 & 0.010 \\
& 0.050 & -0.028 & 0.011 & -0.019 & 0.081 & -0.021 & -0.000 & 0.053 & 0.088 & 0.089 & 0.057 & 0.005 & 0.031
\end{tabular}

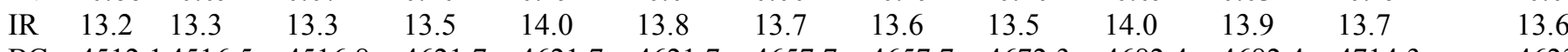

$\begin{array}{lllllllllllll}\mathrm{BC} & 4512.14516 .5 & 4516.8 & 4621.7 & 4621.7 & 4621.7 & 4657.7 & 4657.7 & 4672.3 & 4682.4 & 4682.4 & 4714.3 & 4623.1\end{array}$

\begin{tabular}{llllllllllllll} 
& \multicolumn{10}{c}{2007} & \multicolumn{10}{c}{2007} \\
PP & 0.009 & 0.016 & -0.004 & 0.013 & -0.009 & 0.019 & -0.005 & 0.012 & 0.003 & 0.011 & 0.010 & -0.004 & 0.006 \\
SP & 0.023 & -0.067 & -0.047 & 0.013 & -0.038 & 0.029 & 0.038 & 0.006 & -0.042 & -0.034 & 0.049 & 0.044 & -0.002 \\
IN & 0.37 & 0.33 & 0.26 & 0.14 & -0.05 & -0.93 & -0.33 & 0.04 & -0.05 & 0.02 & -0.12 & 0.06 & -0.02 \\
IR & 13.8 & 13.6 & 13.6 & 13.3 & 13.4 & 13.1 & 13.3 & 13.0 & 12.9 & 13.2 & 13.4 & 13.3 \\
BC & 4867.64867 .6 & 4867.6 & 4973.2 & 4973.2 & 4973.2 & 4973.2 & 4973.2 & 4973.2 & 5064.6 & 5064.6 & 5095.1 & 4972.2
\end{tabular}

$\begin{array}{llllllllllllll}\text { PP } & 0.009 & 0.006 & 0.017 & 0.026 & 0.016 & 0.014 & 0.034 & 0.027 & 0.025 & 0.039 & 0.009 & 0.004 & 0.019 \\ \text { SP } & -0.134 & 0.076 & -0.045 & 0.102 & -0.030 & 0.002 & -0.061 & -0.045 & -0.101 & -0.190 & -0.014 & 0.054 & -0.032 \\ \text { IN } & -0.42 & -0.39 & -0.14 & -0.34 & -0.11 & 0.10 & 0.09 & -0.04 & -0.02 & -0.02 & -0.05 & 0.12 & -0.10 \\ \text { IR } & 13.8 & 13.8 & 14.1 & 13.9 & 14.0 & 14.1 & 13.9 & 13.7 & 13.7 & 14.1 & 14.3 & 14.9 & 14.0 \\ \text { BC } & 5251.5 & 5251.5 & 5251.5 & 5283.1 & 5283.1 & 5283.1 & 5330.4 & 5378.6 & 5378.6 & 5420.9 & 5420.9 & 5420.9 & 5329.5 \\ & & & & & & & & & & & & & \\ \text { PP } & 0.017 & 0.012 & 0.018 & 0.003 & 0.009 & 0.006 & 0.025 & 0.002 & 0.009 & 0.024 & 0.028 & 0.009 & 0.013\end{array}$


Effects of Market Fundamental Variables on Property Prices in Kenya - A Case of ....

\begin{tabular}{|c|c|c|c|c|c|c|c|c|c|c|c|c|c|}
\hline SP & -0.092 & -0.226 & 0.133 & -0.002 & 0.019 & 0.155 & -0.007 & -0.052 & -0.031 & 0.026 & 0.034 & 0.018 & -0.002 \\
\hline IN & 0.14 & -0.10 & 0.01 & 0.16 & 0.18 & 0.00 & -0.05 & 0.06 & 0.06 & 0.04 & 0.19 & -0.12 & 0.05 \\
\hline IR & 14.8 & 14.7 & 14.9 & 14.7 & 14.9 & 15.1 & 14.8 & 14.8 & 14.7 & 14.8 & 14.9 & 14.8 & 14.8 \\
\hline \multirow[t]{2}{*}{$\mathrm{BC}$} & 5429.4 & 45429.4 & 5429.4 & 5450.9 & 5450.9 & 5450.9 & 5490.7 & 5490.7 & 5490.7 & 5507.2 & 5524.6 & 5526.8 & 5472.6 \\
\hline & & & & & & & 2010 & & & & & & 2010 \\
\hline PP & -0.007 & $7-0.004$ & -0.009 & 0.003 & 0.008 & 0.002 & 0.006 & 0.003 & 0.024 & 0.021 & 0.006 & 0.026 & 0.007 \\
\hline SP & 0.098 & 0.018 & 0.122 & 0.039 & 0.002 & 0.023 & 0.023 & 0.004 & 0.039 & 0.007 & -0.057 & 0.009 & 0.027 \\
\hline IN & 0.06 & 0.31 & 0.23 & 0.08 & -0.06 & 0.10 & -0.02 & 0.10 & 0.00 & 0.01 & -0.21 & -0.17 & 0.04 \\
\hline IR & 15.0 & 15.0 & 14.8 & 14.6 & 14.5 & 14.4 & 14.3 & 14.2 & 14.0 & 13.9 & 14.0 & 13.9 & 14.4 \\
\hline \multirow[t]{2}{*}{$\mathrm{BC}$} & 5709.5 & 55715.4 & 5721.7 & 5754.2 & 5740.4 & 5740.4 & 5811.8 & 5806.7 & 5815.6 & 5827.2 & 5839.3 & 5880.2 & 5780.2 \\
\hline & & & & & & & 2011 & & & & & & 2011 \\
\hline PP & 0.016 & 0.012 & 0.015 & 0.009 & 0.001 & 0.008 & -0.004 & 0.003 & -0.009 & -0.009 & 0.002 & 0.000 & 0.004 \\
\hline SP & 0.007 & -0.050 & -0.083 & 0.037 & 0.012 & -0.027 & -0.058 & -0.073 & -0.052 & 0.068 & -0.100 & 0.016 & -0.025 \\
\hline IN & -0.20 & -0.21 & -0.41 & -0.31 & -0.07 & -0.12 & -0.07 & -0.07 & -0.04 & -0.09 & -0.04 & 0.04 & -0.13 \\
\hline IR & 14.0 & 13.9 & 13.9 & 13.9 & 13.9 & 13.9 & 14.1 & 14.3 & 14.8 & 15.2 & 18.5 & 20.0 & 15.0 \\
\hline \multirow[t]{2}{*}{$\mathrm{BC}$} & 5990.0 & 05999.7 & 6019.7 & 6089.6 & 6152.1 & 6168.2 & 6176.5 & 6185.7 & 6195.9 & 6210.0 & 6225.3 & 6236.4 & 6137.4 \\
\hline & & & & & & & 2012 & & & & & & 2012 \\
\hline PP & -0.009 & 90.013 & 0.009 & 0.009 & 0.001 & 0.004 & 0.037 & 0.008 & 0.005 & 0.009 & 0.007 & 0.001 & 0.008 \\
\hline SP & 0.006 & 0.025 & 0.019 & 0.054 & 0.029 & 0.015 & 0.035 & 0.009 & 0.027 & 0.044 & -0.015 & 0.012 & 0.022 \\
\hline IN & 0.03 & 0.09 & 0.07 & 0.16 & 0.06 & 0.18 & 0.23 & 0.21 & 0.13 & 0.22 & 0.21 & 0.02 & 0.13 \\
\hline IR & 19.5 & 20.3 & 20.3 & 20.2 & 20.1 & 20.3 & 20.1 & 20.1 & 19.7 & 19.0 & 17.8 & 18.2 & 19.6 \\
\hline \multirow[t]{2}{*}{$\mathrm{BC}$} & 6365.9 & 96372.3 & 6379.4 & 6388.9 & 6426.6 & 6491.0 & 6509.8 & 6528.7 & 6531.5 & 6534.3 & 6537.0 & 6539.8 & 6467.1 \\
\hline & & & & & & & 2013 & & & & & & 2013 \\
\hline PP & 0.003 & 0.003 & -0.001 & 0.008 & 0.009 & 0.006 & -0.005 & -0.003 & -0.007 & -0.003 & -0.007 & 0.001 & 0.000 \\
\hline SP & 0.069 & 0.023 & 0.076 & -0.020 & 0.051 & -0.082 & 0.041 & -0.019 & 0.020 & 0.030 & 0.033 & -0.034 & 0.016 \\
\hline IN & -0.15 & -0.21 & 0.08 & -0.01 & 0.02 & -0.21 & -0.23 & -0.11 & -0.24 & 0.06 & 0.05 & 0.03 & -0.08 \\
\hline IR & 18.1 & 17.8 & 17.7 & 17.9 & 17.5 & 17.0 & 17.0 & 17.0 & 16.9 & 17.0 & 16.9 & 17.0 & 17.3 \\
\hline \multirow[t]{2}{*}{$\mathrm{BC}$} & 6716.7 & 76742.6 & 6768.7 & 6795.4 & 6821.9 & 6844.3 & 6868.1 & 6895.2 & 6923.3 & 6958.4 & 6987.2 & 7016.7 & 6861.5 \\
\hline & & & & & & & 2014 & & & & & & 2014 \\
\hline PP & 0.009 & 0.004 & 0.006 & -- & -- & -- & -- & -- & -- & -- & -- & -- & 0.006 \\
\hline SP & -0.014 & 40.016 & 0.003 & -- & -- & -- & -- & -- & -- & -- & -- & -- & 0.001 \\
\hline IN & -0.01 & 0.05 & 0.09 & -- & -- & -- & -- & -- & -- & -- & -- & -- & 0.04 \\
\hline IR & 17.0 & 17.1 & 16.9 & -- & -- & -- & -- & -- & -- & -- & -- & -- & 17.0 \\
\hline $\mathrm{BC}$ & 7182.5 & 57213.6 & 7245.2 & -- & -- & -- & -- & -- & -- & -- & -- & -- & 7213.8 \\
\hline
\end{tabular}

Table 1: Schedule of data for the respective variables 
PP

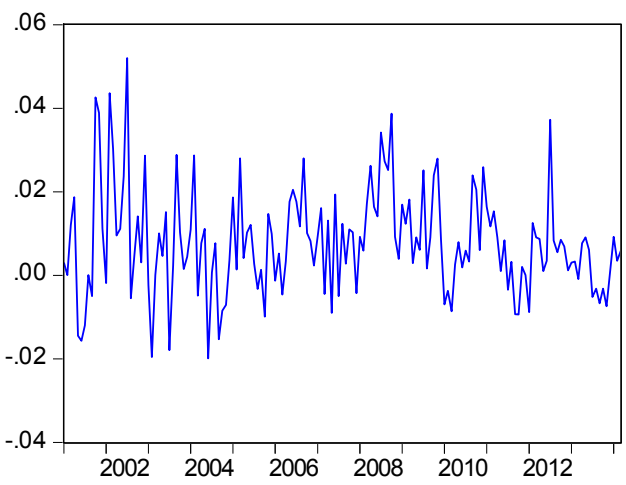

IN

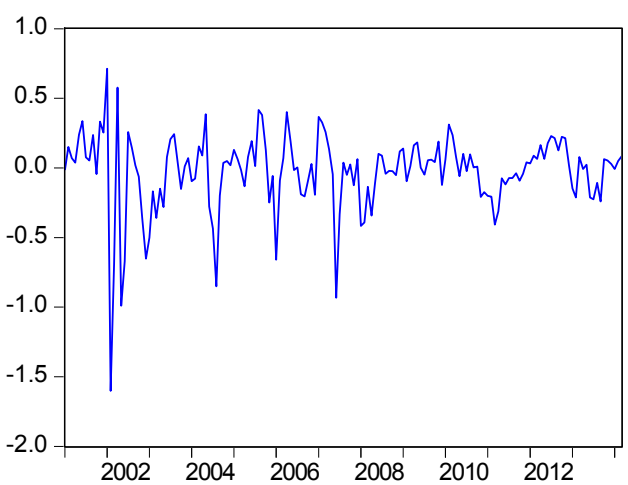

$\mathrm{BC}$

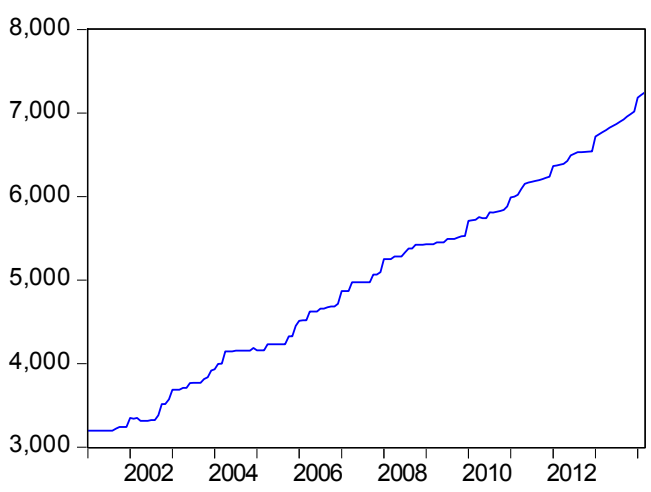

SP

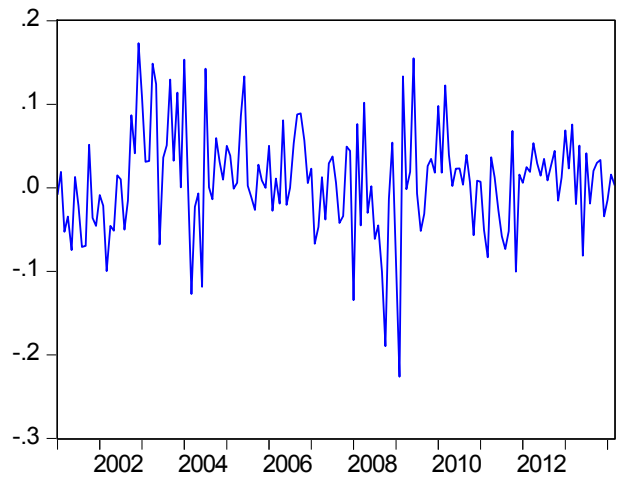

$\mathbb{R}$

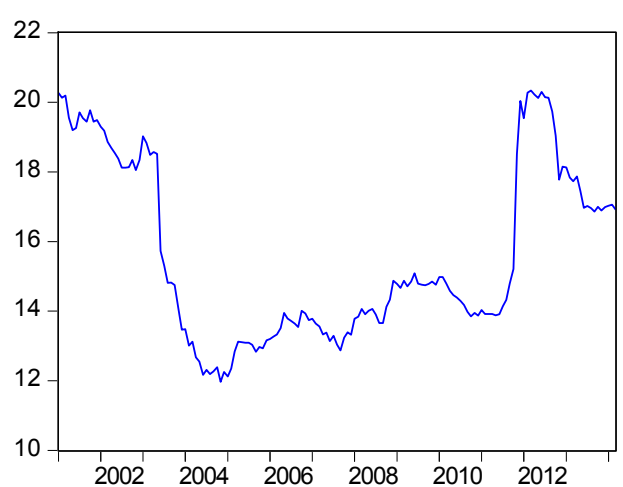

Figure 1: Graphical representation of the data for the variables

\begin{tabular}{lllll}
\hline Variable & $\begin{array}{l}\text { KPSS Test Statistic } \\
\text { (intercept) }\end{array}$ & $\begin{array}{l}\text { KPSS Test Statistic (trend } \\
\text { and intercept) }\end{array}$ & Inference on Integration @ 5\% \\
\hline Property prices & PP & 0.119208 & Not necessary & $\begin{array}{l}\text { I(0) i.e. Accept Ho: PP is Stationary } \\
\text { at level }\end{array}$ \\
\hline Building Cost & BC & 1.544825 & 0.131922 & $\begin{array}{l}\text { I(0) i.e. Accept Ho: BC is Stationary } \\
\text { at level }\end{array}$ \\
\hline Inflation & IN & 0.101783 & Not necessary & $\begin{array}{l}\text { I(0) i.e. Accept Ho: IN is Stationary } \\
\text { at level }\end{array}$ \\
\hline Stock prices & SP & 0.087823 & Not necessary & $\begin{array}{l}\text { I(0) i.e. Accept Ho: SP is Stationary } \\
\text { at level }\end{array}$ \\
\hline Interest rates & IR & 0.296108 & Not necessary & $\begin{array}{l}\text { I(0) i.e. Accept Ho: IR is Stationary } \\
\text { at level }\end{array}$ \\
\hline
\end{tabular}

Table 2: Summary of the results of KPSS Stationarity Tests 
Effects of Market Fundamental Variables on Property Prices in Kenya - A Case of ....

\begin{tabular}{ccccccc}
\hline \hline Lag & LogL & LR & FPE & AIC & SC & HQ \\
\hline \hline 0 & -990.3951 & NA & 0.365919 & 13.18404 & 13.28395 & 13.22463 \\
1 & -222.7460 & 1474.293 & $1.96 \mathrm{e}-05^{*}$ & $3.34769^{*}$ & $3.947089^{*}$ & $3.591161^{*}$ \\
2 & -203.5647 & 35.56805 & $2.12 \mathrm{e}-05$ & 3.424698 & 4.523707 & 3.871172 \\
3 & -182.4589 & $37.73885^{*}$ & $2.23 \mathrm{e}-05$ & 3.476276 & 5.074835 & 4.125694 \\
4 & -164.2604 & 31.33510 & $2.46 \mathrm{e}-05$ & 3.566363 & 5.664471 & 4.418724 \\
5 & -147.8766 & 27.12544 & $2.78 \mathrm{e}-05$ & 3.680485 & 6.278143 & 4.735789 \\
6 & -132.7639 & 24.02015 & $3.20 \mathrm{e}-05$ & 3.811443 & 6.908651 & 5.069690 \\
7 & -119.9958 & 19.44818 & $3.83 \mathrm{e}-05$ & 3.973454 & 7.570212 & 5.434644 \\
8 & -105.0900 & 21.71705 & $4.48 \mathrm{e}-05$ & 4.107152 & 8.203459 & 5.771285 \\
\hline \hline
\end{tabular}

* indicates lag order selected by the criterion

LR: sequential modified LR test statistic (each test at $5 \%$ level)

FPE: Final prediction error

AIC: Akaike information criterion

SC: Schwarz information criterion

HQ: Hannan-Quinn information criterion

Table 3: VAR Lag Order Selection Criteria

\begin{tabular}{|c|c|c|c|c|c|}
\hline & PP & SP & IR & IN & $\mathrm{BC}$ \\
\hline \multirow[t]{3}{*}{$\mathrm{PP}(-1)$} & 0.260027 & -1.082028 & -2.459508 & 1.773982 & -232.6146 \\
\hline & $(0.07959)$ & $(0.39639)$ & $(2.85116)$ & $(1.75775)$ & (266.040) \\
\hline & [3.26710] & {$[-2.72969]$} & {$[-0.86264]$} & [ 1.00923$]$ & {$[-0.87436]$} \\
\hline \multirow[t]{3}{*}{$\mathrm{SP}(-1)$} & -0.001607 & 0.118403 & -0.980229 & -0.089082 & 15.59783 \\
\hline & $(0.01577)$ & $(0.07852)$ & $(0.56477)$ & $(0.34819)$ & $(52.6987)$ \\
\hline & {$[-0.10193]$} & [ 1.50794$]$ & {$[-1.73562]$} & {$[-0.25585]$} & [ 0.29598$]$ \\
\hline \multirow[t]{3}{*}{$\operatorname{IR}(-1)$} & $8.34 \mathrm{E}-05$ & 0.000301 & 0.975092 & 0.005015 & -0.052502 \\
\hline & $(0.00039)$ & $(0.00194)$ & $(0.01397)$ & $(0.00861)$ & (1.30379) \\
\hline & {$[0.21381]$} & [ 0.15492$]$ & [69.7853] & [ 0.58222$]$ & {$[-0.04027]$} \\
\hline \multirow[t]{3}{*}{$\mathrm{IN}(-1)$} & $1.21 \mathrm{E}-06$ & -0.022419 & -0.068608 & 0.266723 & -4.083916 \\
\hline & $(0.00360)$ & $(0.01795)$ & $(0.12910)$ & $(0.07959)$ & $(12.0460)$ \\
\hline & {$[0.00034]$} & {$[-1.24908]$} & {$[-0.53145]$} & [ 3.35126$]$ & {$[-0.33903]$} \\
\hline \multirow[t]{3}{*}{$\mathrm{BC}(-1)$} & $-7.45 \mathrm{E}-07$ & $-2.24 \mathrm{E}-06$ & $5.16 \mathrm{E}-05$ & $1.42 \mathrm{E}-05$ & 1.003614 \\
\hline & (8.7E-07) & $(4.3 \mathrm{E}-06)$ & $(3.1 \mathrm{E}-05)$ & $(1.9 \mathrm{E}-05)$ & $(0.00289)$ \\
\hline & {$[-0.86139]$} & {$[-0.51894]$} & [ 1.66560$]$ & {$[0.74165]$} & [347.031] \\
\hline \multirow[t]{3}{*}{$\mathrm{C}$} & 0.008282 & 0.021436 & 0.134570 & -0.184055 & 10.04112 \\
\hline & $(0.00760)$ & $(0.03786)$ & $(0.27234)$ & $(0.16790)$ & (25.4118) \\
\hline & [ 1.08945] & {$[0.56615]$} & [ 0.49413] & {$[-1.09623]$} & [ 0.39514$]$ \\
\hline $\mathrm{R}$-squared & 0.075652 & 0.067158 & 0.969800 & 0.078401 & 0.998753 \\
\hline Adj. R-squared & 0.045246 & 0.036473 & 0.968807 & 0.048086 & 0.998712 \\
\hline Sum sq. resids & 0.023749 & 0.589094 & 30.47733 & 11.58377 & 265355.8 \\
\hline S.E. equation & 0.012500 & 0.062254 & 0.447782 & 0.276060 & 41.78231 \\
\hline F-statistic & 2.488050 & 2.188598 & 976.2254 & 2.586158 & 24342.72 \\
\hline Log likelihood & 471.2293 & 217.5571 & -94.18896 & -17.76609 & -810.8646 \\
\hline Akaike AIC & -5.888978 & -2.677938 & 1.268215 & 0.300837 & 10.34006 \\
\hline Schwarz SC & -5.772677 & -2.561637 & 1.384516 & 0.417138 & 10.45636 \\
\hline Mean dependent & 0.007909 & 0.008097 & 15.54456 & -0.030441 & 5004.349 \\
\hline S.D. dependent & 0.012793 & 0.063422 & 2.535338 & 0.282946 & 1164.081 \\
\hline \multicolumn{2}{|c|}{ Determinant resid covariance (dof adj.) } & $1.53 \mathrm{E}-05$ & & & \\
\hline \multicolumn{2}{|c|}{ Determinant resid covariance } & $1.26 \mathrm{E}-05$ & & & \\
\hline \multicolumn{2}{|l|}{ Log likelihood } & -229.9839 & & & \\
\hline \multicolumn{2}{|c|}{ Akaike information criterion } & 3.290936 & & & \\
\hline \multicolumn{2}{|c|}{ Schwarz criterion } & 3.872441 & & & \\
\hline
\end{tabular}

Table 4: VAR Estimates results for the selected optimal lag 


\begin{tabular}{|c|c|c|c|c|c|}
\hline & PP & SP & IR & IN & $\mathrm{BC}$ \\
\hline \multirow[t]{3}{*}{$\mathrm{PP}(-1)$} & 0.219143 & -0.932356 & -1.780846 & 1.748746 & -264.4848 \\
\hline & $(0.08423)$ & $(0.42887)$ & $(2.96288)$ & (1.86144) & (279.197) \\
\hline & [ 2.60184] & {$[-2.17400]$} & {$[-0.60105]$} & {$[0.93946]$} & {$[-0.94731]$} \\
\hline \multirow[t]{3}{*}{$\mathrm{PP}(-2)$} & 0.019305 & -0.256003 & -4.398176 & 1.172204 & 233.1425 \\
\hline & $(0.08722)$ & $(0.44412)$ & (3.06829) & $(1.92766)$ & (289.130) \\
\hline & [ 0.22132$]$ & {$[-0.57642]$} & {$[-1.43343]$} & [0.60810] & [ 0.80636$]$ \\
\hline \multirow[t]{3}{*}{$\mathrm{PP}(-3)$} & 0.164952 & 0.172505 & 0.354550 & -2.554999 & 440.9589 \\
\hline & $(0.08581)$ & $(0.43693)$ & $(3.01860)$ & $(1.89645)$ & (284.448) \\
\hline & [ 1.92228$]$ & [ 0.39481$]$ & {$[0.11745]$} & {$[-1.34725]$} & [ 1.55022$]$ \\
\hline \multirow[t]{3}{*}{$\mathrm{SP}(-1)$} & 0.006645 & 0.085697 & -0.941499 & -0.175836 & 29.08549 \\
\hline & $(0.01630)$ & $(0.08297)$ & $(0.57323)$ & $(0.36013)$ & (54.0163) \\
\hline & [ 0.40779$]$ & [ 1.03283$]$ & {$[-1.64245]$} & {$[-0.48825]$} & [ 0.53846$]$ \\
\hline \multirow[t]{3}{*}{$\mathrm{SP}(-2)$} & -0.017796 & 0.092852 & -0.664528 & 0.176769 & -1.758610 \\
\hline & $(0.01648)$ & $(0.08394)$ & $(0.57988)$ & $(0.36431)$ & (54.6428) \\
\hline & {$[-1.07957]$} & [ 1.10623$]$ & {$[-1.14598]$} & {$[0.48522]$} & {$[-0.03218]$} \\
\hline \multirow[t]{3}{*}{$\mathrm{SP}(-3)$} & -0.011233 & 0.138285 & -1.103730 & 0.631565 & 143.0992 \\
\hline & $(0.01632)$ & $(0.08311)$ & $(0.57417)$ & $(0.36072)$ & (54.1048) \\
\hline & {$[-0.68820]$} & [ 1.66390$]$ & {$[-1.92231]$} & [ 1.75083$]$ & [ 2.64485] \\
\hline \multirow[t]{3}{*}{$\operatorname{IR}(-1)$} & 0.002597 & 0.007491 & 1.169337 & -0.017587 & 9.825407 \\
\hline & $(0.00237)$ & $(0.01205)$ & $(0.08324)$ & $(0.05230)$ & (7.84425) \\
\hline & [ 1.09729] & {$[0.62170]$} & [ 14.0471] & {$[-0.33629]$} & [ 1.25256$]$ \\
\hline \multirow[t]{3}{*}{$\operatorname{IR}(-2)$} & -0.004845 & -0.019326 & -0.165966 & 0.046256 & -3.734293 \\
\hline & $(0.00364)$ & $(0.01852)$ & $(0.12792)$ & $(0.08037)$ & $(12.0542)$ \\
\hline & {$[-1.33243]$} & {$[-1.04374]$} & {$[-1.29742]$} & {$[0.57556]$} & {$[-0.30979]$} \\
\hline \multirow[t]{3}{*}{$\operatorname{IR}(-3)$} & 0.002339 & 0.012750 & -0.033076 & -0.024921 & -5.972481 \\
\hline & $(0.00231)$ & $(0.01175)$ & $(0.08116)$ & $(0.05099)$ & (7.64779) \\
\hline & [ 1.01374$]$ & [ 1.08531$]$ & {$[-0.40754]$} & {$[-0.48877]$} & {$[-0.78094]$} \\
\hline \multirow[t]{3}{*}{$\mathrm{IN}(-1)$} & -0.001665 & -0.024487 & -0.022079 & 0.288565 & -12.73258 \\
\hline & $(0.00376)$ & $(0.01915)$ & $(0.13231)$ & $(0.08312)$ & $(12.4675)$ \\
\hline & {$[-0.44278]$} & {$[-1.27865]$} & {$[-0.16688]$} & [ 3.47159$]$ & {$[-1.02126]$} \\
\hline \multirow[t]{3}{*}{$\mathrm{IN}(-2)$} & 0.003530 & 0.005855 & -0.067170 & -0.110968 & 22.65596 \\
\hline & $(0.00390)$ & $(0.01985)$ & $(0.13714)$ & $(0.08616)$ & (12.9231) \\
\hline & [ 0.90549$]$ & [ 0.29495] & {$[-0.48978]$} & {$[-1.28793]$} & [ 1.75314$]$ \\
\hline \multirow[t]{3}{*}{$\mathrm{IN}(-3)$} & 0.006720 & 0.008572 & 0.007378 & 0.144065 & 5.885107 \\
\hline & $(0.00381)$ & $(0.01942)$ & $(0.13416)$ & $(0.08429)$ & (12.6424) \\
\hline & [ 1.76201$]$ & [ 0.44143$]$ & [ 0.05499] & [ 1.70919] & [ 0.46550$]$ \\
\hline \multirow[t]{3}{*}{$\mathrm{BC}(-1)$} & $-1.13 \mathrm{E}-05$ & $7.46 \mathrm{E}-05$ & $6.98 \mathrm{E}-05$ & -0.000725 & 0.897595 \\
\hline & $(2.5 \mathrm{E}-05)$ & $(0.00013)$ & $(0.00087)$ & $(0.00054)$ & $(0.08155)$ \\
\hline & {$[-0.45948]$} & {$[0.59518]$} & {$[0.08070]$} & {$[-1.33302]$} & [ 11.0069] \\
\hline \multirow[t]{3}{*}{$\mathrm{BC}(-2)$} & $7.21 \mathrm{E}-06$ & -0.000124 & -0.000964 & 0.000166 & 0.021218 \\
\hline & $(3.3 \mathrm{E}-05)$ & $(0.00017)$ & $(0.00116)$ & $(0.00073)$ & $(0.10971)$ \\
\hline & [ 0.21773$]$ & {$[-0.73729]$} & {$[-0.82794]$} & {$[0.22632]$} & [ 0.19340$]$ \\
\hline \multirow[t]{3}{*}{$\mathrm{BC}(-3)$} & $3.35 \mathrm{E}-06$ & $4.72 \mathrm{E}-05$ & 0.000935 & 0.000581 & 0.085038 \\
\hline & $(2.4 \mathrm{E}-05)$ & $(0.00012)$ & $(0.00086)$ & $(0.00054)$ & $(0.08092)$ \\
\hline & {$[0.13721]$} & [ 0.37988$]$ & [ 1.08838$]$ & [ 1.07644$]$ & [ 1.05093$]$ \\
\hline \multirow[t]{3}{*}{$\mathrm{C}$} & 0.007881 & 0.010939 & 0.330582 & -0.161573 & 5.955517 \\
\hline & $(0.00780)$ & $(0.03971)$ & $(0.27432)$ & $(0.17234)$ & (25.8497) \\
\hline & [ 1.01068$]$ & [ 0.27549$]$ & [ 1.20509$]$ & {$[-0.93751]$} & [ 0.23039$]$ \\
\hline R-squared & 0.162176 & 0.113573 & 0.972511 & 0.163225 & 0.998856 \\
\hline Adj. R-squared & 0.072409 & 0.018599 & 0.969566 & 0.073570 & 0.998733 \\
\hline Sum sq. resids & 0.021460 & 0.556376 & 26.55535 & 10.48148 & 235801.4 \\
\hline S.E. equation & 0.012381 & 0.063041 & 0.435524 & 0.273620 & 41.04017 \\
\hline F-statistic & 1.806635 & 1.195829 & 330.1957 & 1.820595 & 8149.330 \\
\hline Log likelihood & 472.1779 & 218.2666 & -83.24568 & -10.73520 & -792.3838 \\
\hline Akaike AIC & -5.848435 & -2.593162 & 1.272380 & 0.342759 & 10.36389 \\
\hline Schwarz SC & -5.535629 & -2.280356 & 1.585186 & 0.655565 & 10.67670 \\
\hline
\end{tabular}


Effects of Market Fundamental Variables on Property Prices in Kenya - A Case of ....

\begin{tabular}{|c|c|c|c|c|c|}
\hline Mean dependent & 0.007933 & 0.008418 & 15.48538 & -0.032241 & 5027.534 \\
\hline S.D. dependent & 0.012855 & 0.063635 & 2.496492 & 0.284276 & 1153.184 \\
\hline \multicolumn{2}{|c|}{ Determinant resid covariance (dof adj.) } & $1.38 \mathrm{E}-05$ & & & \\
\hline \multicolumn{2}{|c|}{ Determinant resid covariance } & $8.03 \mathrm{E}-06$ & & & \\
\hline \multicolumn{2}{|c|}{ Log likelihood } & -191.6067 & & & \\
\hline \multicolumn{2}{|c|}{ Akaike information criterion } & 3.482137 & & & \\
\hline \multicolumn{2}{|l|}{ Schwarz criterion } & 5.046166 & & & \\
\hline \multicolumn{6}{|c|}{ Standard errors in ( ) \& t-statistics in [ ] } \\
\hline
\end{tabular}

Table 5: VAR Estimates results for 3 lags

Response to Cholesky One S.D. Innovations \pm 2 S.E.
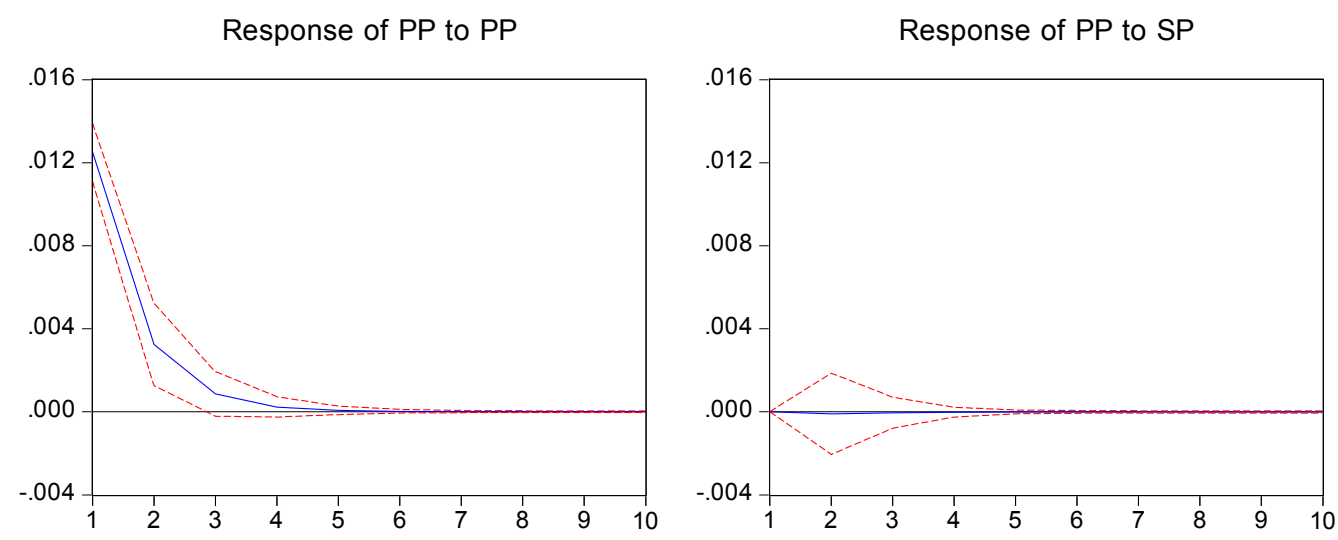

Response of PP to IR



Response of PP to IN

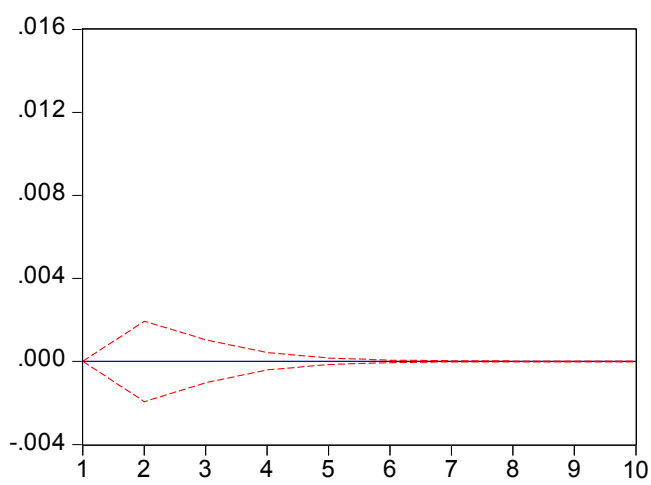

Response of PP to BC

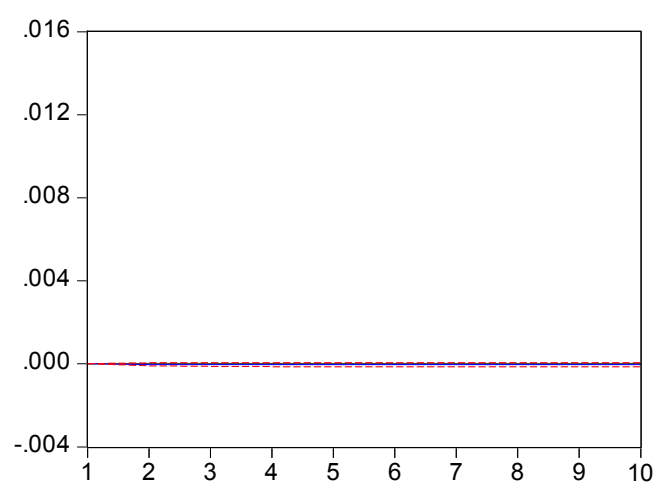

Figure 2: Summary of Impulse Responses of property prices to the respective independent variables 